\title{
Beneish M-score: A measure of fraudulent financial transactions in global environment?
}

\author{
Katarina Valaskova ${ }^{1,}{ }^{*}$, Richard Fedorko ${ }^{2}$ \\ ${ }^{1}$ University of Zilina, Faculty of Operation and Economics of Transport and Communications, \\ Department of Economics, Univerzitna 1, 01026 Zilina, Slovakia \\ ${ }^{2}$ University of Presov, Faculty of Management, Department of Economics, Konstantinova 16, 08001 \\ Presov, Slovakia
}

\begin{abstract}
.
Research background: Earnings is a source of information for capital owners, potential investors, competitors, customer and supplier of the company. Managers have the direct motivation and knowledge and use adequate techniques to adjust legally the reported earnings to meet the specific requirements of the company and achieve stable financial results. Thus, earnings management is currently the most provocative and highly topical issue in the field of finance and accounting at the global perspective. Purpose of the article: The main purpose of the paper is to detect the manipulation with earnings in a specific sector of economy, following the global principles of financial reporting, and to reveal the degree of manipulation of enterprises in the selected countries of the Visegrad grouping.

Methods: The model of Beneish M-score is applied using the sectoral data and compares the level of manipulation in the period 2015-2019. The Beneish model is a mathematical-statistical model that uses financial ratios calculated with accounting data of a specific enterprise aimed to detect if an enterprise is likely that the reported earnings of the company were manipulated.

Findings \& Value added: The paper monitors the development of the manipulation with earnings in the given sector (enterprises tend to manage earnings upwards), and analyses the influences of macroeconomic factors on the phenomenon of earnings management. The detection of earnings management by $\mathrm{M}$-score helps protect business partners of an enterprise against fraudulent behaviour, especially in the global environment.
\end{abstract}

Keywords: earnings management; discretional accrual; non-discretionary accrual; Beneish Mscore, globalization

JEL Classification: $M 48$; $G 30 ; F 60$

\footnotetext{
* Corresponding author: katarina.valaskova@,fpedas.uniza.sk
} 


\section{Introduction}

Companies monitor profit from the accounting aspect, as it is the most important item in the financial statement, quantify profitability in relation to other economic indicators such as costs, equity and total capital, sales, profit before and after taxes and thus characterize the financial and economic situation of the company.

In most cases, profit is considered the highest level of corporate performance. It indicates the extent to which the company is engaged in value-added activities. It is a signal that helps in the direct allocation of resources on the capital markets. The theoretical value of the company's shares is the present value of its future profits. An increase in profit represents an increase in the value of the company and, vice versa, a decrease in profits signals a decrease in value $[1,2]$. Thus, the management of a company generally has a fundamental interest in profit management. For this reason, it is important for executives to understand the implications of their accounting decisions and to be able to make the best decisions for a business unit [3]. Management of enterprises tend to adjust the financial reports to present the best possible results of an enterprise and to build confidence in relation to their business partner. Thus, earnings management practices mean disclosure management in the sense of a purposeful intervention in the external financial reporting process to obtain some private gains [4].

Thus the main purpose of the paper is to detect the manipulation with earnings in a specific sector of economy (using Beneish M-score), following the global principles of financial reporting, and to reveal the degree of manipulation of enterprises in the selected countries of the Visegrad grouping.

The paper is divided into the following sections. The literature review presents the most relevant studies being published in the field of earnings management. The data and methodology section highlights the data used in the analyses as well as the methods used to detect the manipulation with earnings in enterprises of the analysed sector. Results section depicts the crucial findings, discussion analyses the results following the global principles of financial reporting.

\section{Literature Review}

Earnings management has become an interesting issue for several authors around the world in recent decades. Healy [5] was the first to define discretionary accrual, which is an important tool for profit management because they do not require disclosure and audit control is often not required. Accruals are used to identify earnings management, and according to Healy and Wahlen [6] earnings management can be defined as a use of managerial judgment in financial reporting and the structuring of transactions so that the reported economic performance of the company misleads stakeholders and affects relationships with business partners on the reported results.

An interesting and beneficial study was provided by Beneish, Lee, and Nichols [7], who sought to analyse whether the M-score was useful in detecting significant fraudulent practices in financial statement scandals. In this study, M-score revealed $71 \%$ of the most significant financial reporting scandals. Some authors argue $[8,9,10]$, that detecting companies which manipulate their financial statements can be beneficial for the parties concerned - for an investor in the form of increased returns, avoidance of costly litigation for an auditor, and avoidance of damaging reputations for an analyst. The aim of the scientific work was to provide information on the frequency of earnings management in enterprises, analyse the companies where the manipulation was detected and also to identify the determinants of these manipulations. A study of Franceschetti and Koschtial [11] adopted the Beneish M-score as a suitable system for detecting manipulation in the field of earnings management of small 
and medium-sized enterprises. The study showed that companies that are on the verge of bankruptcy do not manipulate earnings or, towards the year of bankruptcy, this manipulation decreases. The research was applied to a sample of 30 standard companies and 30 companies in a bankruptcy. Kaur and Khanna [12] responded to the default of large enterprises, such as Enron, Satyam and Worldcom, stating that this brought much attention to the study of the earnings management phenomenon. Authors analysed the level of management in six popular industries in India: IT, retail, telecommunications, biotechnology, hotels and coffee sectors. They applied two models to detect earnings manipulation: the modified Jones model and the Benenish M-score. They found that the models showed consistent results and filled a research gap in the earnings management literature in India. Anh and Linh [13] used Beneish M-scores on Vietnamese enterprises. The most significant contribution of the study was the finding that the calculation of manipulation scores is a useful technique to determine the behaviour of a manipulator, which can improve the quality of financial statements and protection of investors. Rahmat [14] empirically investigated the ability of Dechow's F-score and Beneish M-score to detect probable manipulators in Malaysia. The study compared models based on error rates. The results show that both models are effective in predicting fraudulent and nonfraudulent companies. Talab et al. [15] uncovered fraud in the financial statements of companies in Iraq using the Beneish M-score. Authors claim that the model application is beneficial for existing and future shareholders to help them make investment decisions and thus reduce the risk of fraud. The likelihood of profit manipulation in Spanish enterprises is estimated in the research of Ramirez-Orellana et al. [16].

Based on the Beneish M-score application, they found that an aggressive accounting practice by manipulating daily sales and total accruals on total assets was used in a selected enterprise. They further stated that the Beneish model indicators such as the sales growth index and the leverage index show possible manipulation and thus their proper use in the calculation of the manipulation score.

\section{Data and Methodology}

To detect the manipulation with earnings in the selected Visegrad countries, the sector of Transporting and storage was chosen for the analysis. The reason is the worsen environment of this sector and the fact that there have been several strikes and complains of carriers considering the tax burden, which can be perceived as one of the incentives of the earnings management. The most affected is the Slovak and Czech transporting sector where the detection of earnings management practices can be revealed. The selected enterprises have to meet several criteria: the limit value of total assets 3 million euros, revenues ( 2 million euros) and net profit of 100,000 euros. Using these limitations, the database of 1,300 Slovak and 3,679 Czech enterprises can be formed. Removing the outlying and extreme values, and considering the selected sector of transporting and storage, the final sample is formed of 68 Slovak and 135 Czech enterprises.

Beneish [17] developed a model that can identify companies which are engaged in manipulation with earnings based on the data from financial statements using eight variables. Model variables are designed to capture either the effects of manipulation or the assumptions that may force enterprises to be engaged in such activities. Beneish model has become very popular worldwide, thus, the M-score is used in the analysis of selected Visegrad countries to detect the earnings management. Beneish M-score uses eight indicators which are grouped into two different categories - indicators of aggressive accounting practices and fraudulent techniques $[8,18,19]$. The M-score is calculated as [17]:

$$
\begin{aligned}
M= & -4.84+0.92 \cdot D S R I+0.528 \cdot G M I+0.404 \cdot A Q I+0.892 \cdot S G I+ \\
& +0.115 \cdot D E P I-0.172 \cdot S G A I-0.327 \cdot L V G I+4.697 \cdot \text { TATA }
\end{aligned}
$$


where

DSRI days sales in receivables index

GMI gross margin index

$A Q I \quad$ asset quality index

SGI sales growth index

$D E P I$ depreciation index

$S G A I \quad$ sales general and administrative expenses index

LVGI leverage index

TATA total accruals to total assets

The limit value of the M-score equals to -2.22. If the calculated manipulation score is less than the limit value, an enterprise is unlikely to be a manipulator. And, vice versa, if the calculated manipulation score is greater that the limit value, an enterprise is likely to manage earnings. The explanatory variables entering the model are based on interannual changes. The data needed to calculate the individual variables entering the Benenish M-score model can be obtained from the financial statements of the companies.

Table 1. Descriptive statistics of analysed variables

\begin{tabular}{|c|c|c|c|c|c|c|c|c|}
\hline & \multicolumn{4}{|c|}{ Slovak Republic (thous. €) } & \multicolumn{4}{|c|}{ Czech Republic (thous.€) } \\
\hline & Mean & Median & St.dev. & $\mathbf{C V}$ & Mean & Median & St.dev. & CV \\
\hline Sales & $26,198.18$ & $16,525.36$ & $27,913.77$ & 1.06 & $52,690.51$ & $19,479.79$ & $183,227.78$ & 3.48 \\
\hline $\begin{array}{l}\text { Tangible } \\
\text { assets }\end{array}$ & $10,320.96$ & $4,810.32$ & $14,546.26$ & 1.41 & $37,059.80$ & $3,032.76$ & $236,438.15$ & 6.38 \\
\hline Total assets & $21,130.38$ & $11,564.46$ & $23,397.60$ & 1.11 & $52,868.01$ & $9,889.66$ & $230,218.35$ & 4.20 \\
\hline Receivables & $4,106.29$ & $2,796.96$ & $5,033.15$ & 1.23 & $7,472.27$ & $2,912.92$ & $21,394.98$ & 2.83 \\
\hline Net profit & $1,374.66$ & 793.66 & $1,788.32$ & 1.30 & $3,097.96$ & 902.52 & $8,254.04$ & 2.63 \\
\hline Gross profit & $1,853.05$ & $1,115.25$ & $2,334.56$ & 1.26 & $3,840.07$ & $1,197.74$ & $10,191.35$ & 2.63 \\
\hline Cash flow & $2,891.61$ & $2,108.10$ & $2,797.54$ & 0.97 & $5,666.52$ & $1,525.03$ & $17,398.95$ & 3.05 \\
\hline Depreciation & $1,516.95$ & 877.41 & $1,756.52$ & 1.16 & $2,568.56$ & 578.16 & $10,829.33$ & 4.22 \\
\hline $\begin{array}{l}\text { Non-current } \\
\text { liabilities }\end{array}$ & $3,720.52$ & $1,280.82$ & $5,874.26$ & 1.57 & $5,115.51$ & 239.72 & $22,310.26$ & 4.35 \\
\hline $\begin{array}{l}\text { Current } \\
\text { assets }\end{array}$ & $9,658.26$ & $5,634.34$ & $11,027.88$ & 1.14 & $17,622.25$ & $5,291.09$ & $51,947.13$ & 2.95 \\
\hline $\begin{array}{l}\text { Current } \\
\text { liabilities }\end{array}$ & $5,771.46$ & $4,167.53$ & $5,847.67$ & 1.01 & $12,405.25$ & $3,346.68$ & $47,714.79$ & 3.87 \\
\hline
\end{tabular}

Note: st.dev (standard deviation), CV (coefficient of variance)

The total calculation includes 11 variables, which are listed in Table 1 together with their descriptive statistics to create an overview of the data obtained. The presented values are the three-year average for the monitored periods 2015-2018. For the purposes of the paper, the financial data were downloaded from the Amadeus database.

The research is then organized in several methodological steps. Firstly, each of the eight indicators is calculated for each company in the database, for both Slovak and Czech business environments (and for each analysed period). Secondly, the average values were determined. Each indicator is assessed separately, as its individual values may reveal the first incentives of the manipulation. Thirdly, the M-score is calculated for the transporting and storage sector in Slovak and Czech enterprises. The earnings management practices are detected, analysing 
the manipulation score achieved. Finally, the results are compered within the countries and the manipulation with earnings is detected.

\section{Results}

The results of individual indicators entering the Beneish model are firstly analysed. The value of the indicators can reveal the potential earnings manipulation - if the interannual comparison exceeds the value of 1 . The values of all indicators can be calculated in the consequent three years (using the data of 2015-2018).

Table 2 summarizes the three-year average values of the indicators in both countries.

Table 2. Average values of indicators in the sector of transporting and storage

\begin{tabular}{|l|c|c|c|c|c|c|}
\hline \multirow{2}{*}{ Indicator } & \multicolumn{3}{|c|}{ Slovak republic } & \multicolumn{3}{c|}{ Czech republic } \\
\cline { 2 - 7 } & $\mathbf{2 0 1 8 / 2 0 1 7}$ & $\mathbf{2 0 1 7 / 2 0 1 6}$ & $\mathbf{2 0 1 6 / 2 0 1 5}$ & $\mathbf{2 0 1 8} / \mathbf{2 0 1 7}$ & $\mathbf{2 0 1 7 / 2 0 1 6}$ & $\mathbf{2 0 1 6 / 2 0 1 5}$ \\
\hline DSRI & 1.09 & 1.28 & 1.05 & 1.24 & 1.09 & 2.39 \\
\hline GMI & 0.99 & 1.09 & 1.00 & 0.98 & 0.98 & 1.00 \\
\hline AQI & 4.70 & 4.48 & 2.59 & 8.33 & 6.79 & 4.60 \\
\hline SGI & 1.09 & 1.04 & 1.10 & 1.11 & 1.02 & 1.08 \\
\hline DEPI & 0.99 & 1.02 & 1.07 & 0.92 & 1.55 & 1.07 \\
\hline SGAI & 1.10 & 1.19 & 1.21 & 2.27 & 1.33 & 1.14 \\
\hline LVGI & 1.00 & 1.01 & 0.94 & 1.03 & 0.99 & 0.99 \\
\hline TATA & 0.37 & 1.32 & 0.98 & 0.59 & 1.17 & 0.93 \\
\hline
\end{tabular}

DSRI compares the ratio of receivables to sales in current period to the previous period. The calculated value is the highest in 2017 for Slovakia and 2016 in the Czech Republic. GMI calculates the gross margin of the previous period to the gross margin of the current year. The values of this indicator are very close to zero in each analyse period (the value is slightly over the limit in 2017 in Slovakia), indicating the gross margins were not deteriorated; usually there is a positive dependence between GMI and probability of earnings management practices [20,21]. AQI index analyses the ratio of non-current assets to total assets in current year to the previous one. As indicated in the table, the values are several times higher than the limit value which demonstrates that enterprises are involved in costs accruals. Considering the results of assets quality index it is evident that enterprises of both countries have positive relation to earnings manipulation. SGI index presents the ration of current sales to previous-year sales. The growth of this indicator does not automatically signify the manipulation with earnings, but an unreasonable growth may be a sign of fraudulent practices for auditors and professional authorities. Depreciation index contrasts the rate of depreciation in previous year to the corresponding period. If this indicator is greater than 1, the depreciation rate was slowed down [17, 22] and the possibility of manipulation increases. The calculated results are very close to zero, or only slightly exceeds the limit value, except for 2017 in the Czech Republic revealing aggressive manipulation practices (either increased estimates of the asset value or adoption of a new method). SGAI index compares sales general and administrative expenses of this year to the previous year expenses. As discussed by Lev and Thiagarajan [20] huge increase in sales may cause financial problems in the future. Considering the values of SGAI index, positive relation can be determined, with the highest values in 2018 in the Czech Republic. LVGI is the rate of total debts to total assets compared in the year-on-year period. In both countries, the index is slightly below of very close to zero, which does not imply an increase in the leverage. Total accruals to total assets ratio is included to measure the impact of managerial decision to alter earnings, higher positive accruals indicate the potential use of earnings management.

Analysing the individual input variables of the Beneish model, it is evident, that the enterprises are likely to manage earnings to achieve any benefits or improve the financial 
statements. To detect the manipulation with earnings in the sector, the Beneish M-score was calculated for the sample of Slovak enterprises. The score greater than -2.22 indicates the earnings manipulation, the results (revealing the number of enterprises with earnings management) are portrayed in Table 3.

Table 3. Detected manipulation in Slovak enterprises

\begin{tabular}{|l|c|c|c|}
\hline & $\mathbf{2 0 1 8}$ & $\mathbf{2 0 1 7}$ & $\mathbf{2 0 1 6}$ \\
\hline Total & 53 & 53 & 68 \\
\hline \% of the sample & $78 \%$ & $78 \%$ & $100 \%$ \\
\hline
\end{tabular}

Despite the fact, that there is the same number of enterprises with detected manipulation of earnings, they are not the same. Thus the following table (Table 4) demonstrates the number of enterprises which manipulates in one, two or all three years. The results claim, that 46 enterprises used the manipulation in the whole analysed period.

Table 4. Number of manipulating Slovak enterprises in the analysed period

\begin{tabular}{|l|c|c|c|}
\hline & 1 year & 2 years & 3 years \\
\hline Total & 8 & 14 & 46 \\
\hline \% of the sample & $12 \%$ & $21 \%$ & $68 \%$ \\
\hline
\end{tabular}

Very similar results may be portrayed also in the Czech Republic. The highest number of manipulated enterprises was detected in 2016 - almost $97 \%$ of all cases in the database (Table 5).

Table 5. Detected manipulation in Czech enterprises

\begin{tabular}{|l|c|c|c|}
\hline & $\mathbf{2 0 1 8}$ & $\mathbf{2 0 1 7}$ & $\mathbf{2 0 1 6}$ \\
\hline Total & 84 & 84 & 131 \\
\hline \% of the sample & $62 \%$ & $62 \%$ & $97 \%$ \\
\hline
\end{tabular}

As in the case of Slovak companies, this is not a 100 percent match of the companies that manipulated in 2017 and 2018. The selection process showed different combinations of periods in the companies in which they show manipulation. Table 6 shows the numbers of Czech companies that manipulated earnings in one, two or in all three monitored periods.

Table 6. Number of manipulating Czech enterprises in the analysed period

\begin{tabular}{|l|c|c|c|}
\hline & 1 year & 2 years & 3 years \\
\hline Total & 29 & 45 & 60 \\
\hline \% of the sample & $21 \%$ & $33 \%$ & $44 \%$ \\
\hline
\end{tabular}

In the database of Czech enterprises, there is also one company, which did not report earnings management practices in any of the analysed years.

The results of manipulation score in transporting enterprises of both countries reveal, that these business entities tend to manage earnings to achieve better performance of their enterprises - both managerial and financial. Applying the calculation in the same sector, the results can be easily compared, as also the national, economic and legal measures of both countries are very similar. $97 \%$ of enterprises operating in the Czech Republic manipulated their earnings in 2016, while in the given year all Slovak companies reported possible profit manipulation. In 2017, the number of manipulating companies represented $78 \%$ of the industry in Slovakia and $62 \%$ in the Czech Republic. In 2018, calculation show the same number of companies as in 2017 for both Slovakia and the Czech Republic. The following figure (Figure 1) shows the trends in earning management practices in transporting enterprises of both countries. 


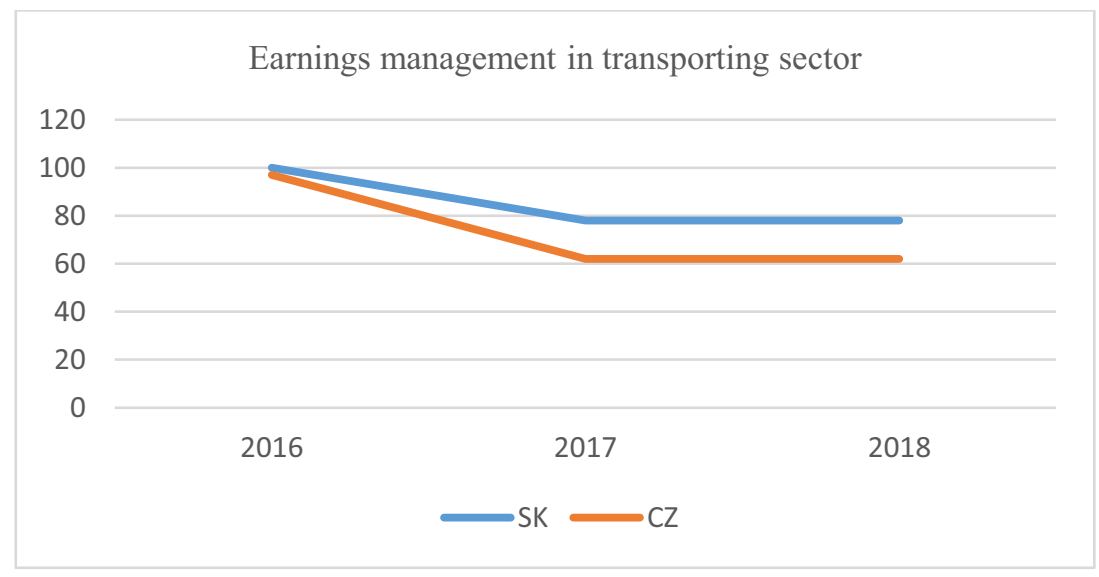

Fig. 1. Comparison of detected manipulation

The graphics processing of the results unveiled that based on the calculation of the Benenish M-score model, Slovak enterprises have a greater participation in profit manipulation. However, in the case of both countries, the year-on-year decrease in the number of companies participating in manipulation of earnings is evident, which may be a consequence of stricter legislation.

\section{Discussion}

The Beneish M-score model was used to identify enterprise which manipulate earnings, their numbers, shares in the overall industry, but also the behaviour of these companies within the analysed period. When detecting the earnings management, a difference in the number of manipulating enterprises was found in Slovakia and the Czech Republic.

In the Slovak Republic, it is possible to match the incentive for profit management in enterprises operating in the NACE H sector, with the reason for launching the strike of the union of road hauliers in Slovakia. At the turn of 2019 and 2020, they announced a strike in which they pointed to the long-term deteriorating conditions in transport. The reason is the long-term increase of burden in road tax, excise tax, tax on mineral oils and the revelation of the Supreme Audit Office of the Slovak Republic on uneconomical toll collection. The Slovak Republic is the second country in the European Union to have the highest taxes on a combination trailer. Nevertheless, the revenue from taxes and fees in Slovakia accounts only for $2.3 \%$ of GDP, which is the same level as the European Union average. The two main conditions to stop the strike were a reduction in road tax by $50 \%$ and the suspension of toll collection until the resolution of irregularities from the report of the Supreme Audit Office of the Slovak Republic [23, 24]. These facts may be the main reason for the year-on-year increase in the share of enterprises in the NACE-SK H - Transport and storage section, which managed their earnings.

It is also interesting to analyse the evidence of earnings manipulation calculated by the Beneish M-score and macroeconomic impacts on the manipulation of companies. For the analysis of macroeconomic impact, the data from the Global Competitiveness Reports for the periods 2015-2016, 2016-2017 and 2017-2018 were chosen. The list of factors is made up by experts and economists of the World Economic Forum, which selects the most problematic factors for doing business in the countries. The most problematic factors for doing business in a given country may be perceived as a crucial incentive for earnings management in the analysed companies. The score was determined by economic experts and published in the 
GCI report. For each monitored period, five factors with the greatest impact on the business environment were identified (Table 7).

Table 7. The most problematic factors of business environment in Slovak and Czech republics

\begin{tabular}{|l|r|r|r|r|r|r|}
\hline & \multicolumn{3}{|c|}{ Slovak republic } & \multicolumn{3}{c|}{ Czech republic } \\
\hline & $2015-16$ & $2016-17$ & $2017-18$ & $2015-16$ & $2016-17$ & $2017-18$ \\
\hline Corruption & 18.1 & 19.2 & 8.3 & 13.2 & 11.3 & 9.6 \\
\hline Bureaucracy & 16.6 & 14.8 & 4.3 & 21.8 & 19.7 & 16.9 \\
\hline Taxation (rate) & 11.4 & 17.2 & 15.8 & 5.7 & 10.0 & 10.9 \\
\hline Restrictive labour regulations & 11.3 & 8.9 & 3.8 & 7.6 & 7.0 & 8.3 \\
\hline Tax regulation & 9.5 & 10.8 & 8.8 & 10.4 & 16.0 & 17.6 \\
\hline Unstable policy & 8.8 & 5.6 & 4.6 & 12.7 & 10.6 & 9.8 \\
\hline Low educated labour force & 6.6 & 7.4 & 6.9 & 7.1 & 7.3 & 7.3 \\
\hline Access to finance & 3.5 & 1.6 & 21.1 & 3.5 & 3.7 & 2.8 \\
\hline
\end{tabular}

Table 7 summarizes the most problematic factors for each monitored period for the Slovak Republic. For the period 2015-2016, these are: corruption, bureaucracy, tax rates, restrictive labour regulations and tax regulations. For the period 2016-2017: corruption, tax rates, bureaucracy, tax regulations and restrictive labour regulations. In the last monitored period, there is a change and the most problematic factor is considered to be the approach to financing. In the case of the Czech Republic, these are mostly the same factors as in the case of the Slovak Republic. The top five in 2015-2016 include: bureaucracy, corruption, policy instability, tax regulations and restrictive labour regulations. In the period 2016-2017, the most problematic factors for doing business were: bureaucracy, tax regulations, corruption, policy instability and tax rates. Recently, the most problematic factors are tax regulations, followed by bureaucracy, tax rates, policy instability and corruption.

It can be concluded that it is not possible to clearly determine the impact of these factors on the increase or decrease in the number of identified manipulating enterprises in the analysed period. However, it is evident, that changing taxation, corruption and tax regulation do play an important role. The analysed transporting and storage enterprises may react differently to different changes in the structure of factors. Based on these facts, the main objective of the paper to detect the manipulation with earnings in a specific sector of economy following the global principles of financial reporting and to reveal the degree of earnings manipulation was met using the Beniesh M-score model. The theoretical contribution of the paper is the awareness in the field of earnings management detection, the practical one is the use of the Beneish model for the detection of earnings manipulation using the financial statements of enterprises. The study is limited only to a sectoral analysis (Nace $\mathrm{H}-$ Transporting and storage), but this limitation will be eliminated in further research focusing on the application of the Beneish M score in the global context.

This research was financially supported by the Ministry of Education, Science, Research and Sport of the Slovak Republic and Slovak Academy of Sciences VEGA 1/0121/20: Research of transfer pricing system as a tool to measure the performance of national and multinational companies in the context of earnings management in conditions of the Slovak Republic and V4 countries. 


\section{References}

1. Majercak, P., Kliestik, T., Masarova, G., Buc, D, Majercakova, E. (2013). System Approach of Logistic Costs Optimization Solution in Supply Chain. Nase More, 60(56), 95-98.

2. Makka, K., Kampova, K., Boros, M. (2019). Workplace training in the fuels distribution company. In L. Goméz Chova, A. Lopez Martine \& I. Candel Torres (Eds), 13th International Technology, Education and Development Conference (INTED2019) (pp. 3990-3995. Valencia: IATED Academy.

3. McKee, T.E. (2005). Earnings management: An Executive Perspective. Boston: Cengage Learning.

4. Schipper, K. (1989). Commentar on Earnings Management. Accounting Horizons, 3, 91102.

5. Healy, P.M. (1985). The efect of bonus schemes on accounting decisions. Journal of Accounting and Economics, 7, 85-107.

6. Healy, P. M., Wahlen, J.M. (1999). A Review of the Earnings Management Literature and its Implications for Standard Setting. Accounting Horizons, 13, 365-383.

7. Beneish, M.D., Lee, M.C., Nichols, C. (2013). Earnings Manipulation and Expected Returns. Financial Analysts Journal, 69(2), 57-82.

8. Svabova, L., Kramarova, K., Chutka, J., Strakova, L. (2020). Detecting earnings manipulation and fraudulent financial reporting in Slovakia. Oeconomia Copernicana, 11(3), 485-508.

9. Ayu, M., Gamayuni, R.R., Urbański, M. (2020). The impact of environmental and social costs disclosure on financial performance mediating by earning management. Polish Journal of Management Studies, 21(1), 74-86.

10. Siekelova, A., Androniceanu, A., Durana P., Frajtova Michalikova, K. (2020). Earnings management (EM), initiatives and company size: An empirical study. Acta Polytechnica Hungarica, 17(9), 41-56.

11. Franceschetti, B.M., Koschtial, C. (2013). Do bankrupt companies manipulate earnings more than the nonbankrupt ones? Journal of Finance and Accountancy, 12, 1-22.

12. Kaur, R., Khanna, A. (2014). Detecting Earnings Management in India: A sector-wise study. European Journal of Bussiness and Management, 6(11), 11-19.

13. Anh, H.N., Linh, H.N. (2016). Using the M-score Model in Detecting Earnings Management: Evidence from Non-Financial Vietnamese Listed Companies. NU Journal of Science: Economics and Business, 32(2), 14-23.

14. Rahmat, M.M. (2016). Detecting Financial Statement Frauds in Malaysia: Comparing the Abilities of Beneish and Dechow Models. Asian Journal of Accountning and Governance, 7, 57-65.

15. Talab, R.H., Hakeem, H.F., Sallama, A.I.(2017). Role of Beneish M-score Model in Detecting of Earnings Management Practices : Empirical study in listed banks of Iraqi Stock Exchange. International Journal of Applied Business and Economic Research, 15(23), 203-287.

16. Ramirez-Orellana, A., Martinez-Romero, M., Marino-Garrido, T. (2016). Measuring fraud and earnings management by a case of study: Evidence from and international family business. European Journal of Family Business, 7(1-2), 41-53.

17. Beneish, M. (1999). The detection of earnings management. Idiana: Indiana University. 
18. Tuffnell, C., Kral, P., Durana, P., Krulicky, T. (2019). Industry 4.0-based Manufacturing Systems: Smart Production, Sustainable Supply Chain Networks, and Real-Time Process Monitoring. Journal of Self-Governance and Management Economics, 7(2), 712.

19. Khuong, N.V., Liem, N.T., Minh, M.T.H. 2020. Earnings management and cash holdings: Evidence from energy firms in Vietnam. Journal of International Studies, 13(1), 247-261.

20. Lev, B., Thiagarajan, S.R. (1993). Fundamental Information Analysis. Journal of Accounting Research, 31(2), 190-215.

21. Kampova, K., Makka, K., Zvarikova, K. (2020). Cost benefit analysis within organization security management. In T. Kliestik (Ed.). 19th International Scientific Conference Globalization and Its Socio-Economic Consequences 2019 - Sustainability in the Global-Knowledge Economy (Art. No. 01010). France: EDP Sciences.

22. Kampova, K., Makka, K., Zvakova, Z., Pellowski, W. (2018). In F. Jakab (Ed.), 16th International Conference on Emerging Elearning Technologies and Appplications (pp. 261-266). USA: IEEE.

23. Majercak, P., Cisko, S., Majercakova, E. (2013). The impact of theory of constraints on the management accounting. In T. Loster \& T. Pavelka (Eds.). 7th International Days of Statistics (pp. 894-904). Slany: Melandrium.

24. Majercak, P., Majercakova, E., Nedeliakova, E. (2014). Management of Optimization in Logistics Leads to Savings in Transport Costs. In R. Kersys (Ed.). 18th International Conference on Transport Means (pp. 364-367). Kaunas: University of Technology. 